\title{
Molecular Screening for MYMV Resistance in Interspecific Hybrids of Vigna raidiata with Wild Vigna sp. using Tobacco N Gene Primers
}

\author{
P. Sivakumar ${ }^{1 *}$, M. Pandiyan ${ }^{2}$ and A. Manickam ${ }^{3}$
}

${ }^{1}$ Department of Crop Improvement, Agricultural College and Research Institute, Tamil Nadu Agricultural University, Eachangkottai, Thanjavur-614 902, India

${ }^{2}$ Department of Crop Improvement, Agricultural College and Research Institute, Tamil Nadu Agricultural University, Vazhavachanur, Thiruvannamalai - 606 753, India

${ }^{3}$ Centre for Plant Molecular Biology and Biotechnology, Tamil Nadu Agricultural University, Coimbatore-641 003, India

*Corresponding author

\section{A B S T R A C T}

\section{Keywords}

Mungbean, MYMV resistance, Tobacco $\mathrm{N}$ gene primers, Inter specific hybrids

Article Info

Accepted:

18 May 2020

Available Online:

10 June 2020
Interspecific hybridization was made between mungbean yellow mosaic virus (MYMV) susceptible greengram variety CO 5 with MYMV resistant wild Vigna sp. Crossed seeds were raised in field condition for testing the MYMV incidence. $F_{1}$ showed dominant resistance reaction against MYMV disease incidence. The field growing $\mathrm{F}_{2}$ populations of $\mathrm{C} 05 \mathrm{x}$ wild Vigna sp, cross produced a wide range of segregant viz., susceptible, parental and intermediate type. $\mathrm{F}_{2}$ progenies were subjected to $\mathrm{PCR}$ amplification using tobacco $\mathrm{N}$ gene primers designed based on the tobacco N-gene and Arabidopsis RPS gene sequences. The PCR reaction was carried out and expected product was amplified at annealing temperature at $40^{\circ} \mathrm{C}$. In parental polymorphisms, a detectable single band of 500bp being present in MYMV resistant Wild Vigna species, which was absent in MYMV susceptible CO 5 greengram variety. All the $\mathrm{F}_{2}$ resistant individuals showed 500bp DNA band with use of the same tobacco $\mathrm{N}$ gene primers.

\section{Introduction}

Greengram, Vigna radiata (L) Wilczek is one of the important, ancient and well-known grain legume in almost all states of India. It is an excellent source of easily digestable and good quality protein for the growing population in many developing countries of south Asia and south-east Asia (Surashi et al., 2017). Greengram seeds are favoured for their digestible protein with low flatulence, rich in phosphorus, provitamin-A and are relatively free from anti-nutritional factors (Adsule et al., 1986). Greengram seed contains high amount of protein and lysine and or low amount of methonine amino-acid 
profile compliment to cereals to form a balanced amino acid diet (Shahrajabian et al., 2019). Greengram is widely grown in India and other countries like Pakistan, USA and Australia. India accounts for more than twothird of total production of greengram, for example annual production of greengram in Tamil Nadu is 1.21 lakhs tonnes cultivated in 1.89 lakhs ha with an average yield of 642 $\mathrm{kg} / \mathrm{ha}$ (Mariyammal et al., 2019). There are several biotic and abiotic factors are responsible for low productivity in greengram crop. Among the biotic stresses, the MYMV disease cause serious yield loss up to $85 \%$. MYMV disease can be controlled by different methods (Paul et al., 2013). Among the different methods, the host resistance alone is a best method of choice to control the MYMV diseases for long period.

Utilization of wild species for improving their cultivated counterparts is steadily increasing in various crops where genetic diversity in the primary gene pool is limited. The wild relatives of greengram such as $V$. umbellata, $V$. vexillata, $V$. trilobata and other wild $V$. spp. carrying desirable genes for many yield components coupled with resistance to MYMV. The use of wild Vigna species in greengram breeding programme has been difficult because of problems encountered in obtaining successful $\mathrm{F}_{1}$ hybrids between cultivated and wild Vigna spp. due to crossability barriers. In spite of these difficulties, interspecific hybridization between $V$. radiata and its wild relatives of Vigna was successfully accomplished by many researchers (Renganayaki, 1985; Pandae et al., 1990; Ganeshram 1993; Subramanian and Muthiah, 2000; Umamaheswari, 2002; Sidhu and Satija, 2003; Pandiyan et al., 2010; Pandiyan et al., 2012; Sudha et al., 2013; Chitra et al., 2018; Basavaraja et al., 2019). Developing molecular markers or cloning genes of traits known only phenotypically is not an easy task; mungbean yellow mosaic disease is one such category. However, a handful of plant disease resistance $(R)$ genes have been recently cloned by transposon tagging or map based cloning. These approaches are, on the other hand, time consuming and cumbersome. However, many laboratories followed Polymerase Chain Reaction (PCR)-based approach for isolating and using $\mathrm{R}$ genes and or Resistant Gene Analogous (RGA) for identification of MYMV resistance in greengram genotypes (Kabi et al., 2017; Sai et al., 2017; Patel et al., 2018; Sing et al., 2018). In the present study the occurrence of $R$ gene (tobacco $\mathrm{N}$ gene) sequences was tested in the progenies derived from greengram with wild Vigna species for MYMV resistance.

\section{Materials and Methods}

The parental greengram (Var. CO 5) seed material was obtained from Department of Pulses, Centre for Plant Breeding and Genetics, Tamil Nadu Agricultural University, Coimbatore, and Vigna wild species was collected from Top slip area of Tamil Nadu. The ovule parents Var.C0 5 and tester parent (wild Vigna sp.) was raised in rows to accommodate 10 plants per row with an intra row $30 \mathrm{~cm}$. The female parent was crossed with pollen parent and the crossed seeds were collected carefully. The emasculation and crossing in greengram were exercised following the procedure developed by Boling et al., (1961). $F_{1}$ seeds were raised in the field for assessing the MYMV resistance based on morphological characters. The infector row method was followed for assessing the MYMV reaction in both $F_{1}$ and $\mathrm{F}_{2}$ populations. The susceptible greengram variety CO 5 was planted every $10^{\text {th }}$ row of planting as the check (Singh, 1980).

The present study was also carried out with an aim to tag the MYMV resistance gene by using tobacco $\mathrm{N}$ gene primers. The amino 
acid sequence homology between these two gene was $100 \%$ restricted to two short regions one in the kinase-1a or P-loof motif (GGVGKTT; Sarste et al., 1990) of the nucleotide-binding site (NBS) and the second (GLPLAL; Mindrinos et al., 1994) approximately 160 amino acids further downstream. The consensus sequences and possible primers are noted below.

\section{Extraction of plant genomic DNA}

A modified CTAB (Cetyl trimethyl ammonium bromide) DNA extraction technique of Gawel and Jarret, (1991) was followed to extract the genomic DNA from leaf tissue.

\section{Primer sequences used for PCR}

N'terminal sequence $G \quad G \quad V \quad G \quad K \quad T \quad T$ Forward 5' -GGI GGI GTI GGI AAI ACI AC- 3'

C' terminal sequence $G \quad L \quad P \quad L \quad A \quad L$ Reverse 5' -IAG IGC IAG IGG IAG ICC - 3'

The PCR was performed for both parents and progenies The présence and absence désirable band of through agarose gel electrophoresis (Sambrook et al., 1989)

\section{Results and Discussion}

\section{Expeditions and evaluation of wild Vigna $s p$}

The expeditions and collection of wild Vigna sp. in resistance to yellow mosaic virus disease was carried out at two different places viz., top slip area of Tamil Nadu and Kotaimaidan (Western Ghat) area of Kerala. Among the expeditions, one wild Vigna species was collected from Top slip area of Tamil Nadu. The collected wild Vigna species was raised in the field for assessing the yellow mosaic virus incidence using susceptible variety $\mathrm{CO} 5$ as check. The collected wild Vigna species was phenotypically similar to cultivated Vigna species (Fig.1- $\mathrm{P}_{2}$ ). The flower buds, pod and seed colours were closely resembles the cultivated Vigna species. The collected wild Vigna species was phenotypically resistant to yellow mosaic viral disease.

\section{Evaluation of $F_{1}$ and $F_{2}$ segregants}

Interspecific hybrdization has been made between MYMV susceptible greengram variety $\mathrm{CO}$ with MYMV resistant wild Vigna $s p$ and F1 plants were produced (Fig. 1). The hybridization was done with more than 500 flowers and obtained only few pods (12-15 seeds). The occurrence of low pod and seed set is mainly due occurrence of pre and post fertilization barriers. These results are agree with the findings of Gopinathan et al., (1986), Mendioro and Ramirez, (1994), James et al., (1999), Uma Maheshwari (2002), Pandiyan et al., (2010) and Chitra et al., (2018). The field raised $F_{1}$ plants showed dominant resistance reaction against MYMV disease incidence. A similar finding was also reported by Jain et al., (2013) in mungbean varietal crosses. The selfed seeds of the $F_{1}$ hybrid was collected and raised in the field for evaluating the MYMV incidence. The segregating population produced a wide range of segregant viz., susceptible, parental and intermediate type (Fig 2). $\mathrm{F}_{2}$ population produced a wide range of segregants viz., susceptible, parental and intermediate types (Fig. 2). Similarly, Satija and Ravi (1996) reported that hybrids of the cross $V$. radiata $\mathrm{x}$ $V$. umbellata were either transgressive or intermediate compared to their parents. Earlier same findings also reported for the production of fertile hybrids with intermediate phenotypes compared to both the parents (Monika et al., 2001; Uma Maheswari, 2002; Sidhu and Satija, 2003; Chitra et al., 2018; 
Basavaraja et al., 2019). These results are also agree with the results of Parida et al., (1985), Subramanian and Muthiah, (2000), Premkumar et al., (2007), Pandiyan et al., (2010), Sudha et al., (2013) and Chitra et al., (2018) in interspecific hybridization of Vigna species.

\section{Molecular screening $F_{2}$ population by using tobacco $\mathbf{N}$ gene primers}

In order to understand whether there are $\mathrm{R}$ Gene sequences whose products contain NBS and LRR motifs in mungbean, the $F_{2}$ progenies DNA subjected to PCR amplification using tobacco $\mathrm{N}$ gene primers designed based on the tobacco $\mathrm{N}$-gene and Arabidopsis RPS gene sequences. The PCR reaction was carried out and expected product was amplified at annealing temperature at $40^{\circ} \mathrm{C}$. In parental polymorphisms, a detectable single band of 500bp being present in MYMV resistant Wild Vigna species, which was absent in MYMV susceptible $\mathrm{CO} 5$ greengram variety. All the $F_{2}$ resistant individuals showed 500bp DNA band with use of the same tobacco $\mathrm{N}$ gene primers (Fig. 3). This band corresponds to the product size expected from the primers designed as evidenced in studies on potato (Leister et al., 1996) and soybean (Yu et al., 1996). Whitham et al., (1996) demonstrated that the tobacco $\mathrm{N}$ gene confers a hypersensitive responsive to tobacco mosaic virus (TMV) disease in transgenic tomato. He also found the expression of $\mathrm{N}$ gene is effectively inhibit and systemic movement of TMV in transgenic tomato.
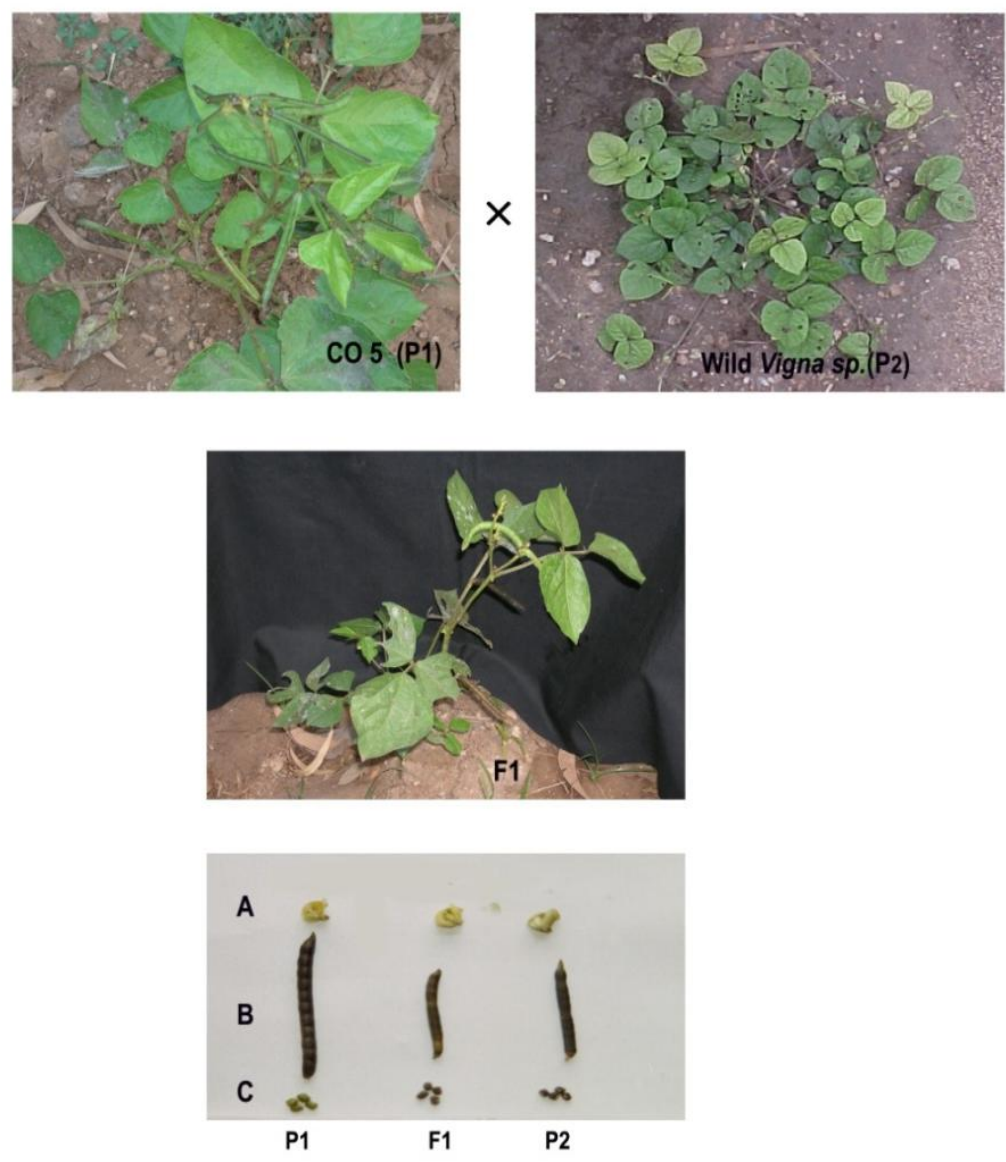

(A- Flower bud, B- Pod, C-Seed)

Fig. $1 \mathrm{~F}_{1}$ cross of CO5 greengram $\times$ Wild Vigna $s p$. 

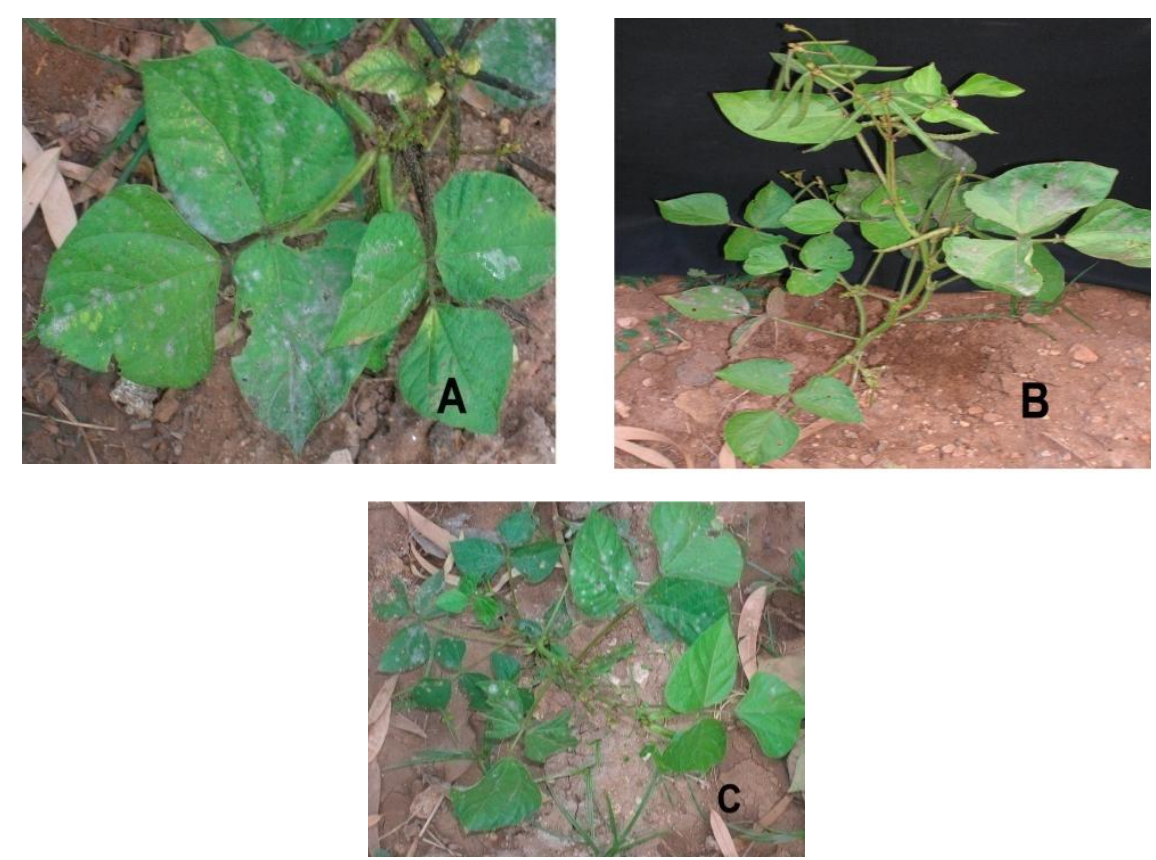

(A- Susceptible B- Resemble to CO 5 parent C-Intermediate-Hybrid)

Fig.2 $\mathrm{F}_{2}$ sergeants of CO $5 \times$ wild Vigna sp.

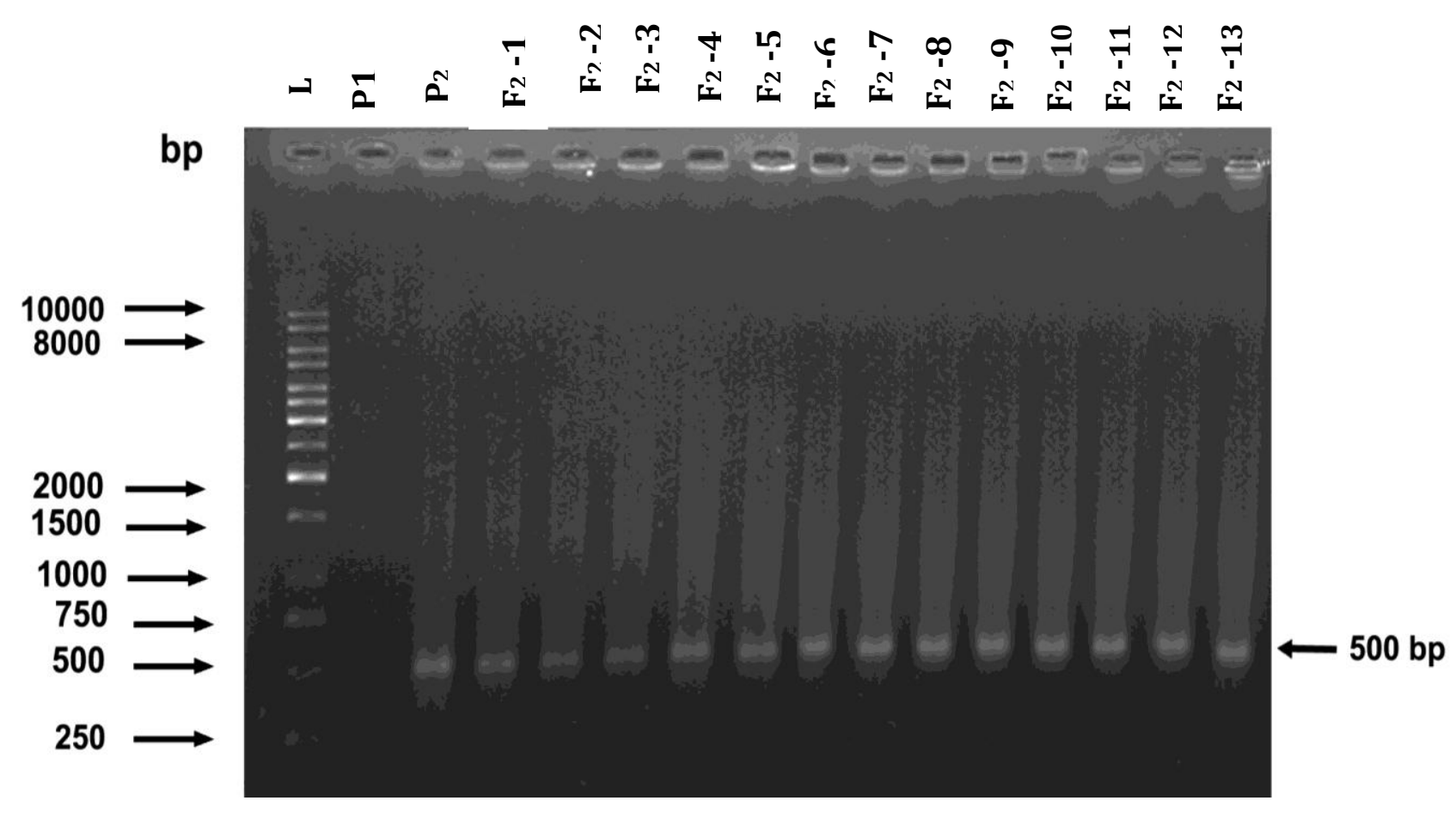

(L-DNA ladder; $\mathrm{P}_{1}-\mathrm{Co} 5 ; \mathrm{P}_{2}$ - Wild Vigna sp.)

Fig.3 PCR profile of parental and $\mathrm{F}_{2}$ resistant individuals using Tobacco $\mathrm{N}$ gene primers

In the present study, the expeditions and search for MYMV resistant wild Vigna species was undertaken and collected one wild Vigna species. The Vigna species was phenotypically resistant to MYMV. Interspecific hybridization was made between elite, MYMV susceptible greengram Var. CO $5 \times$ wild Vigna $s p$. and progenies followed up 
to $\mathrm{F}_{2}$ generation. In molecular analysis, all $\mathrm{F}_{2}$ Progenies, wild Vigna sp. amplified a 500bp DNA products and susceptible parent CO 5 didn't yield any characteristic PCR products using tobacco $\mathrm{N}$ gene-primer sequences.

\section{References}

Adsule, R.N., S.S. Kadam, D.K. Salunkhe, B.S. Luh, 1986. Chemistry and technology of green gram (Vigna radiata [L.] Wilczek). Critical Reviews in Food Science and Nutrition. 25(1):73-105.

Basavaraja, T., M. Niranjana, L. Vijay Kumar, K. Mallikarjun. 2019. Studies on cross compatibility in interspecific crosses of Vigna radiata $\times$ Vigna umbellata species. Legume research An international Journal. 42:5:699-704

Boling, M., D.A. Sander, R.S. Matlock. 1961. Mungbean hybridization technique. Agronomy Journal.53:54-55.

Chitra, S., T. Kalaimagal, T. Thirumurugan. 2018. Development of MYMV resistant prebreeding lines in mungbean (Vigna radiata) through interspecific hybridization. Int J Curr Microbiol App Sci., 7(01):2674-2677.

Ganeshram, S. 1993. Evaluation of some genotypes interspecific hybrids and derivatives of greengram ( $V$. radiata (L.) Wilczek $\mathrm{x}$ Blackgram (Vigna mungo (L.) Hepper) crosses. M.Sc. (Ag.) Thesis, Tamil Nadu Agricultural University ,Coimbatore

Gawel, N.J., and R.L. Jarret. 1991. A modified CTAB DNA extraction procedure for Musa and Ipomoea. Plant Mol Biol Rep. 9:262-266.

Gopinathan, M.C., C.R. Babu, K.R. Shivanna.1986. Interspecific hybridization between rice bean $(V$. umbellata) and its wild relative ( $V$. minima): Fertility $\quad-\quad$ Sterility Relationships, Euphytica. 35:1017-
1022.

Jain, R., G. Roopa Lavanya, P. Ashok Reddy, G.S Babu. 2013. Genetic inheritance of yellow mosaic virus resistance in mungbean [Vigna radiata (L.) Wilczek]. Trends in Bioscience. 6:305306.

James, A.T, R.J. Lawn, R.W. Williams, C.J. Lambrides, C.J. 1999. Cross fertility of Australian accessions of wild mungbean (Vigna radiata spp. sublobata) with green gram ( $V$. radiata $\mathrm{spp}$. radiata) and black gram ( $V$. mungo). Aust $\mathrm{J}$ Bot. 47:601-610

Kabi, M., T.R. Das, B. Baisakh, D. Swain. 2017. Resistant gene rnalogous marker assisted selection of yellow mosaic virus resistant genotypes in Greengram (Vigna radiata). Int J Curr Microbiol App Sci. 6(9):3247-3252.

Leister, D.A., F. Ballvora, D. Salamini, C. Gebhardt. 1996. A PCR based approach for isolating pathogen resistance genes from potato with a potential for wide application in plants. Nature Genet. 14:421-429.

Mariyammal, I., M. Pandiyan, C. Vanniarajan, J.S. Kennedy, N. Senthil. 2019. Genetic variability in segregating generations of greengram (Vigna radiata L. Wilczek) for quantitative traits. Electronic Journal of Plant Breeding. 10(1):293-296.

Mendioro, M.S. and D.A. Ramirez. 1994. Post - fertilization barriers in interspecific hybridization (Vigna radiata (1.) Wilczek, V. mungo (L..) Hepper, V. glabrescens, and their reciprocal crosses. Phil Agric. 3:359 382.

Mindrinos, M., F. Katagiri, G.L. Yu, F.M. Ausubel. 1994. The A. thaliana disease resistance gene RPS2 encodes a protein containing a nucleotide-binding site and leucine-rich repeats. Cell. 79:10891099. 
Monika, K., P. Singh, P.K. Sareen. 2001. Cytogenetic studies in mungbeanricebean hybrids. J. Cytol Genet. 2:1316.

Pandae, K., S.S. Raghavanshi, P. Prakesh. P. 1990. Induced high yielding amphiploid of Vigna radiata x Vigna mungo. Cytologia. 55:249-253.

Pandiyan, M., N. Senthil, N. Ramamoorthi, A.R. Muthiah, N. Tomooka, V. Duncan, T. Jayaraj. 2010. Interspecific hybridization of Vigna radiata x 13 wild Vigna species for developing MYMV donar. Electronic Journal of Plant Breeding. 1(4):600-610.

Pandiyan, M., N. Senthil, R. Suersh, N. Chakravarthy, D. Packiaraj, S. Jagadeesh. 2012. Interspecific hybridization of Vigna radiata x Vigna trilobata. Wudpecker Journal of Agricultural Research. 1(6):233-234.

Parida, D.and D.P.Singh. 1985. Performance of wide and varietal crosses of mung bean. Indian J Genet. 45(1):12 -15.

Patel, P., K. Modha, C. Kapadia, G. Vadodariya, R. Patel. 2018. Validation of DNA Markers Linked to MYMV Resistance in Mungbean (Vigna radiata (L). R. Wilczek). Int J Pure App Biosci. 6(4):340-346.

Paul, P.C., M.K. Biswass, D. Mandal, P. Paul. 2013. Studies on host resistance of mungbean against Mungbean Yellow Mosaic Virus in the agro-ecological condition of lateritic zone of west Bengal. The Bio scan. 8(2):583-587.

Premkumar, N., M. Pandiyan. P. Veerabadhiran. 2007. Prefertilization barriers in Vigna radiatax Vigna umbellata. Plant Archives, 7(1): 377380.

Renganayaki, K. 1985. Studies on genetic differentiation between three species of VignaSavi. M.Sc.(Ag.)Thesis,Tamil Nadu Agricultural University, Coimbatore.
Sai, C.B., P. Nagarajan, M. Raveendran, R. Rabindran, N. Senthil. 2017. Understanding the inheritance of mungbean yellow mosaic virus (MYMV) resistance in mungbean (Vigna radiata L. Wilczek). Molecular breeding. 37:63.

Sambrook J., EF Fritsch and $\mathrm{T}$ Maniatis. 1989. Molecular cloning. A laboratory manual. Cold Spring Harbor Laboratory Press, Cold Spring harbor, New York.

Saraste, M., P.R. Sibbald, A. Wittinghofer. 1990. The P-loopA common motif in ATP- and GTP-binding proteins. Trends Biochem Sci. 15:430-434.

Satija, C.K., and Ravi. 1996. Cytomorphological studies in hybrids and amphidiploids of $\mathrm{V}$. radiata $\mathrm{x} V$. umbellata. Crop Improvement. 23:19-24 Shahrajabian, M.H., W.Sun, Q. Cheng. 2019.A short review of health benefits and nutritional values of mung bean in sustainable agriculture. Polish Journal of Agronomy. 37:31-36.

Sidhu, N., and C.K. Satija. 2003. Cytomorphological characterization of amphidiploids of Vigna radiata $\mathrm{x} V$. umbellata. Crop Improvement. 30(1):25-32.

Singh, D.P. 1980. Inheritance of resistance to YMV in blackgram. Theor Appl Genet. 57:233-235.

Singh, N., J. Mallick, D. Sagolsem, N. Mandal, S. Bhattacharyya. 2018. Mapping of molecular markers linked with MYMIV and yield attributing traits in mungbean. Indian $\mathrm{J}$ Genet. 78(1):118-126.

Subramanian, A., and A.R. Muthiah. 2000. Interspecific hybridization between $V$. radiata (L.) Wilczek and blackgram $V$. mungo (L.) Hepper. Legume Research. 24(3):154-158.

Sudha, M., A. Karthikeyan, P. Anusuya, N.M. Ganesh, M. Pandiyan, N. Senthil, M. Raveendra, M. P. Nagarajan, K. 
Angappan, 2013. Inheritance of resistance to mungbean yellow mosaic virus (MYMV) in inter and intra specific crosses of mungbean (Vigna radiata). American Journal of Plant Sciences. 4(10):1924-19276

Surashe, S.M., D.K. Patil, V.K. Gite. 2017. Combining Ability for Yield and Yield Attributes Characters in Greengram (Vigna radiata L. Wilczek). Int J Curr Microbiol App Sci. 6(11):3552-3558.

Umamaheswari, D. 2002. Wide hybridization in the genus Vigna. M.Sc. (Ag.) Thesis, TNAU, Coimbatore.
Whitham, S., S. McCormick. B. Baker. 1996. The $\mathrm{N}$ gene of tobacco confers resistance to tobacco mosaic virus in transgenic tomato. Proceedings of the National Academy of Sciences. 93(16):8776-8781.

Yu, Y.G., G.R. Buss, M.A. Saghai-Maroof. 1996. Isolation of a superfamily of candidate disease resistance genes in soybean based on a conserved nucleotide binding site. Proceedings of the National Academy of Sciences. 93:11751-11756.

\section{How to cite this article:}

Sivakumar. P. M., Pandiyan and Manickam. A. 2020. Molecular Screening for MYMV Resistance in Interspecific Hybrids of Vigna raidiata with Wild Vigna sp. using Tobacco N Gene Primers. Int.J.Curr.Microbiol.App.Sci. 9(06): 1372-1379.

doi: https://doi.org/10.20546/ijcmas.2020.906.169 